Introduction: Lung cancer holds the first position as the number of deaths among both the genders and, even if oncological efficient, is related to lasting psychological effects, which may significantly influence further functioning of a patient's professional and social life. The researches objective was to find the level of acceptance of lung cancer and to determine what is the patient's readiness to accept the changes in life after the surgery.

Material and methods: In total, 135 patients suffering from lung cancer were enrolled. To evaluate the readiness to accept the changes in life after the surgery the authors' questionnaire was used and to evaluate of level of acceptance of illness the standardized the Acceptance of Illness Scale (AIS) was used.

Results: The awareness of the treatment consequences is high among the patients scheduled for surgery. The acceptance of lung cancer is high (mean $=32.23 ; S D=7.53)$. The level of disease acceptance depends on the evaluation of own health - both currently (it is higher among the patients who consider their health as good) and compared to the previous year (it is higher among the patients who evaluate it as the same or better than a year ago) $(p<0.05)$. The willingness to accept the life changes depends on a gender, age, marital status, education, employment and health orientation $(p<0.05)$.

Conclusions: Regardless of the achievements of the recent years in the lung cancer treatment, it remains the biggest oncologic challenge worldwide. Only multidisciplinary actions including prevention and psycholog ical support may contribute to much more efficient treatment.

Key words: lung cancer, surgery, acceptance changes after lung cancer.

Contemp Oncol (Pozn) 2020; 24 (1): 42-50 DOI: https://doi.org/10.5114/wo.2020.94729

\section{The patient's readiness to accept the changes in life after the radical lung cancer surgery}

\author{
Kinga Gryglicka ${ }^{1}$, Katarzyna Białek ${ }^{2}$
}

${ }^{1}$ Clinical Department of Thoracic Surgery and Oncological Surgery with Pulmonary Rehabilitation Subdivision, The John Paul II Specialist Hospital in Krakow, Poland ${ }^{2}$ Institute of Medical Sciences, Faculty of Medicine and Health Sciences, Jan Kochanowski University, Kielce, Poland

\section{Introduction}

Lung cancer is the most common malignant cancer in men and the second most frequent in women [1]. It ranks fifth among the worst prognostic tumors, the main cause of which is late diagnosis [2]. Almost as many people die every year from lung cancer as new cases are registered. According to data published by the National Cancer Registry, it is the most common malignant cancer leading to death in both men and women [3]. In Poland $80 \%$ of all diagnosed lung cancers belong to the group of non-small cell lung cancers. The remaining diagnosed cancers are small cell carcinomas (17\%) and other types of lung cancers, including sarcomas and carcinoids (3\%) [4].

The treatment of non-small cell lung cancer at an early stage is surgical treatment or combined surgical and systemic treatment aimed at complete removal of the tumor within anatomical boundaries, as well as excision of lymph nodes that may be potential sites of regional metastases [5]. Of all lung cancer patients treated surgically, about $50 \%$ survive 5 years, and of those operated at the earliest stage of the disease - over 80\% [6].

Lung cancer is a very mentally charging type of cancer, which is conditioned by a number of factors, which can be divided into two groups: clinical and personality-social. The former includes late detection, rapid course of the disease and poor prognosis [7]. The source of anxiety may also be related to the hospital environment and numerous therapeutic interventions [8]. Compared to other cancers, the course of lung cancer is fast and multi-symptomatic, with some ailments, such as dyspnea or hemoptysis, seeming to be extremely stressful. After lung resection the image of oneself and one's body may also change. The dominant feeling of guilt in the patient is also noteworthy, which is related to, among others, habitual smoking (very common among lung cancer patients) and the feeling of inability to influence one's fate. The social aspect of the disease should also be mentioned, because of which the patient must find himself/herself in a new situation. Very often the patient is forced to change his or her lifestyle and submit to restrictions related to its course, which results in increased anxiety in simple social situations and interpersonal difficulties [9].

Some lung cancer patients may never even achieve adequate mental adaptation to the disease [10]. Therefore, an important part of treatment is to provide support for the patient and his/her family and to properly recognize how patients perceive the situation in which they find themselves [11], to help them adapt to cancer and to restore their mental balance. De Walden-Gałuszko [7] points to two objectives of such adaptation: the first is to deal with the problems of the disease, and the second is to deal with the changes in the quality of life caused by it.

Acceptance of cancer and its limitations allows the patient to rationally assess the situation, restoring functional and emotional balance and a sense 
of control over their own health and life. The greater the acceptance of the disease, the better the adaptation to it and the less mental discomfort [12]. The literature includes many reports on the level of disease acceptance in patients treated for various types of cancer, including lung cancer. However, it is much more difficult to find publications on the acceptance of limitations related to the course of the disease itself and the consequences of treatment. The aim of this study was therefore to determine the degree of disease acceptance and to analyze what factors influence the readiness of lung cancer patients to accept functional limitations after surgical treatment.

\section{Material and methods}

The study involved 135 patients hospitalized in the Department of Thoracic Surgery Clinic of Jagiellonian University Collegium Medicum in the period from July 2016 to April 2017 and qualified for radical lung resection due to diagnosed lung cancer. Patients and the Bioethics Committee (No. 135/KBL/OIL/2016 of 15 July 2016) have granted consent to conduct the study. The qualification of subjects was strictly defined and included specific inclusion and exclusion criteria:

The inclusion criteria:

- diagnosed lung cancer eligible for surgical treatment,

- aged over 18 years.

The exclusion criteria:

- aged under 18 years,

- no patient's consent to participate in the study,

- a result $<24$ points obtained in the Mini-Mental State Examination (MMSE) screening test.

The author's questionnaire was used to collect the data. It included questions of single choice of sociometric data, such as gender, age, marital status, family status, education, employment, residence and questions concerning subjective evaluation of the patient's health and well-being. In the questionnaire patients were also asked to subjectively assess their readiness to accept life changes after lung cancer surgery. The list of 17 factors was prepared on the basis of literature and conversations with doctors about difficulties experienced by patients in the course of the disease and possible further postoperative treatment. These included changes in lifestyle (no addictions), reduced physical effort, lack of ability to work, deprivation of social contacts, chronic fatigue, dependence on other people, frequent hospital stays, chemotherapy or other forms of further treatment, frequent infections, dyspnea, dependence on oxygen therapy, relapse of cancer, physical pain or death. The assessment of each factor was made on a scale from 1 to 5, where 1 means "I strongly disagree" and 5 means "I strongly agree".

The degree of disease acceptance in the study group was determined by the standardized questionnaire Acceptance of Illness Scale (AIS) by Felton et al. [13] in the Polish adaptation of Juczyński [12]. The questionnaire contains eight statements describing the consequences of ill health, which boil down to accepting the limitations imposed by the disease, lack of self-sufficiency, sense of dependence on others and reduced self-esteem. The higher the acceptance of the illness, the better the adaptation to it and the less mental discomfort. The answers have been grouped according to a point value (1-5), where 1 means "I strongly agree" and 5 means "I strongly disagree". The sum of all points is a general measure of the degree of acceptance of the disease, and its range is between 8 and 40 points. AIS has good psychometric properties, for which Cronbach's $\alpha$ is 0.82 and the stability index is 0.69 .

Moreover, MMSE test has been used as the inclusion/exclusion criterion. The objective was to qualify the patient for the study by excluding dementia. The authors of the test are Folstein, Folstein, and McHugh [14], whereas the present paper uses the 2001 edition by Folstein, Folstein, and Fanjiang in the Polish adaptation of Stańczak [15]. The MMSE test consists of 30 questions/tasks allowing for quantitative evaluation of various aspects of cognitive functioning. Areas of evaluation include orientation in place and time, remembering, attention, recalling, naming, repeating, understanding and reading. The test is used for screening of cognitive dysfunctions. The highest possible score is 30 points. It is assumed that obtaining 24 to 26 points by the examined person may indicate the presence of mild cognitive impairment $(\mathrm{MCl})$. A score below 24 points indicating mild to profound dementia was therefore assumed as a criterion for disqualifying the patient from further examination procedure.

Statistical analyses were carried out with the use of R program, version 3.4.0. The materiality level of 0.05 was assumed in the analysis [16].

\section{Results}

The study involved 135 patients with lung cancer, including 88 men (65.19\%) and 47 women (34.81\%). The average age of respondents was 63.8 years $(S D=10.3)$ and ranged from 30 to 87 years. Out of 135 patients 108 (80\%) were married, 18 (13.33\%) were widowed and 9 (6.67\%) were unmarried. Out of the whole group, 55 respondents (40.74\%) had two children, 48 (35.56\%) three or more, and $32(23.7 \%)$ one or no children at all. The vast majority in the examined group are people with primary or secondary education ( $n=64,47.41 \%)$ and rural residents $(n=52$, $38.52 \%)$. The highest percentage of the surveyed were those with a pension and/or disability benefit $(n=91$, $67.41 \%$ ). $99.26 \%$ of patients were lonely or lived with the family. One person $(0.74 \%)$ did not answer this question. Considering the subjective sense of health, 80 patients (59.26\%) considered themselves healthy, 48 (35.56\%) considered themselves ill, and 7 people (5.19\%) could not assess this. When asked about their general state of health as many as 99 (73.33\%) of treated patients declared it as good, 23 (17.04\%) as very good and 13 (9.63\%) as bad. Comparing the current state of health and that of a year before, 68 patients (50.37\%) believed that their health was the same as the year before, 63 (46.67\%) that it was worse, and $4(2.96 \%)$ that it was better than the year before. The vast majority of respondents ( $n=133,98.52 \%)$ were aware of the consequences and outcomes of treatment.

The AIS was used to assess the negative consequences of the well-being of the treated patients. The lower the degree of disease acceptance, the worse the adaptation 
Table 1. Acceptance of lung cancer. Descriptive statistics for the results of the Acceptance of Illness Scale (AIS) scale

\begin{tabular}{ccccccccc}
\multicolumn{10}{c}{ AIS (points) } \\
\hline$n$ & Average & SD & Median & Min & Max & Q1 & Q3 \\
135 & 32.23 & 7.53 & 34 & 12 & 40 & 27
\end{tabular}

Table 2. The degree of acceptance of the disease and the perception of own health of the patients treated (I consider myself a person...)

\begin{tabular}{|c|c|c|c|c|c|c|c|c|c|}
\hline \multirow{2}{*}{$\begin{array}{l}\text { Perception of own } \\
\text { health }\end{array}$} & \multicolumn{8}{|c|}{ AIS (points) } & \multirow[t]{2}{*}{$p^{*}$} \\
\hline & $n$ & Average & SD & Median & Min & Max & Q1 & Q3 & \\
\hline Healthy & 80 & 34.06 & 6.71 & 36 & 17 & 40 & 30.75 & 40 & 0.004 \\
\hline III & 48 & 29.91 & 8.11 & 31 & 12 & 40 & 24 & 36.25 & \\
\hline
\end{tabular}

AIS - Acceptance of Illness Scale, ${ }^{\star}$ Mann-Whitney test

Table 3. The degree of acceptance of the disease and the assessment of the state of health by patients compared to the state a year ago

\begin{tabular}{|c|c|c|c|c|c|c|c|c|c|}
\hline \multirow{2}{*}{$\begin{array}{l}\text { Health assessment compared } \\
\text { to the year before }\end{array}$} & \multicolumn{8}{|c|}{ AIS (points) } & \multirow[t]{2}{*}{$p^{*}$} \\
\hline & $n$ & Average & SD & Median & Min & Max & Q1 & Q3 & \\
\hline Same or better than last year & 72 & 33.61 & 7.14 & 36 & 14 & 40 & 29 & 40 & 0.013 \\
\hline Worse than last year & 63 & 30.65 & 7.72 & 33 & 12 & 40 & 24.5 & 37 & \\
\hline
\end{tabular}

AIS - Acceptance of Illness Scale, ${ }^{*}$ Mann-Whitney test

Table 4. The degree of disease acceptance and the assessment of the state of health of the examined patients

\begin{tabular}{|c|c|c|c|c|c|c|c|c|c|}
\hline \multirow{2}{*}{$\begin{array}{l}\text { Assessment of the state of } \\
\text { health }\end{array}$} & \multirow[b]{2}{*}{$n$} & \multicolumn{7}{|c|}{ AIS (points) } & \multirow[t]{2}{*}{$p^{*}$} \\
\hline & & Average & SD & Median & Min & $\operatorname{Max}$ & Q1 & Q3 & \\
\hline Very good health (Vg) & 23 & 34.78 & 6.07 & 37 & 20 & 40 & 30.5 & 40 & 0.005 \\
\hline Good health (G) & 99 & 32.52 & 7.26 & 34 & 14 & 40 & 29 & 39 & Vg, G \\
\hline Bad health condition (Bh) & 13 & 25.45 & 8.52 & 24 & 12 & 40 & 20 & 28.57 & $>\mathrm{Bh}$ \\
\hline
\end{tabular}

AIS - Acceptance of Illness Scale, ${ }^{*}$ Kruskal-Wallis test + post-hoc analysis results (Dunn test)

and greater the sense of mental discomfort. For the examined persons, the assessments were summed up and the overall result, which indicates the degree of disease acceptance, was calculated. The mean value of the general AIS index obtained for all 135 patients was 32.23 points (SD = 7.53), which means high degree of disease acceptance. The median was 34 points, so half of the respondents received 34 points and less, and half of them received 34 points and more. The first and third quartile were 27 and 39 points, respectively, which means that a typical result in the studied group is within this range. The summary of results obtained in AIS is presented in Table 1.

The analysis conducted with the use of Mann-Whitney $U$ test shows that such variables as own health perception and its evaluation in comparison with the previous year had a statistically significant impact on the degree of disease acceptance in the examined patients. In patients who consider themselves healthy and those who consider them the same or better than the year before, the degree of disease acceptance is higher $(p<0.05)$. These values are presented in Tables 2 and 3.

The analysis of AIS dependence and general health assessment was performed using Kruskal-Wallis test. It was noted that the p-value is lower than 0.05 , so the degree of disease acceptance depends on the assessment of health condition. To see how exactly this dependence looks like, a post-hoc analysis was performed. It was noted that patients assessing their health condition as good or very good significantly more accepted their disease than patients assessing it as bad ( $p<0.05)$ (Table 4).

Variables such as gender, age, marital status, number of children, education, employment, place of residence did not determine the level of disease acceptance $(p>0.05)$.

Patients were declared to subjectively assess their readiness to accept life changes after lung cancer surgery. The analysis of quantitative variables was performed by calculating the mean, standard deviation, median, quartiles and ranges of values of individual variables.

It has been shown that lung cancer patients were most willing to accept changes in lifestyle (getting rid of addictions), and least of all - dependence on oxygen therapy, relapse of cancer, death and dyspnea. This classification is presented in Table 5.

Further, it was checked how individual variables affect the readiness of lung cancer patients to accept functional limitations after surgical treatment.

Based on the research and statistical analysis using the Mann-Whitney $U$ test, $p$-values lower than 0.05 were recorded for 6 out of 17 analyzed consequences of the surgery, which means that the susceptibility to accept functional limitations after surgery depended on gender. Women were less likely than men to accept chemotherapy 
Table 5. The readiness of treated patients to accept changes after lung cancer surgery

\begin{tabular}{|c|c|c|c|c|c|c|c|c|}
\hline Changes after surgery & $n$ & Average & SD & Median & Min & Max & Q1 & Q3 \\
\hline Changes in lifestyle (no addictions) & 135 & 4.44 & 0.78 & 5 & 1 & 5 & 4 & 5 \\
\hline $\begin{array}{l}\text { Chemotherapy or other forms of further } \\
\text { treatment }\end{array}$ & 135 & 3.3 & 1.27 & 4 & 1 & 5 & 2 & 4 \\
\hline Reduced various forms of sport activity & 135 & 3.26 & 1.22 & 4 & 1 & 5 & 2 & 4 \\
\hline Reduced physical effort & 135 & 3.24 & 1.21 & 4 & 1 & 5 & 2 & 4 \\
\hline Deprivation of social contacts & 135 & 3.16 & 1.19 & 4 & 1 & 5 & 2 & 4 \\
\hline $\begin{array}{l}\text { Shortening the time to prepare various } \\
\text { activities }\end{array}$ & 135 & 3.16 & 1.23 & 4 & 1 & 5 & 2 & 4 \\
\hline Lack of ability to work & $134^{*}$ & 3.1 & 1.23 & 4 & 1 & 5 & 2 & 4 \\
\hline Dependence on other people & 135 & 2.89 & 1.26 & 3 & 1 & 5 & 2 & 4 \\
\hline Physical pain & 135 & 2.77 & 1.08 & 3 & 1 & 4 & 2 & 4 \\
\hline Frequent infections & 135 & 2.71 & 1.18 & 2 & 1 & 4 & 2 & 4 \\
\hline Frequent hospital stays & 135 & 2.7 & 1.2 & 2 & 1 & 5 & 2 & 4 \\
\hline Chronic exhaustion & 135 & 2.7 & 1.18 & 2 & 1 & 5 & 2 & 4 \\
\hline Chronic fatigue & 135 & 2.68 & 1.23 & 2 & 1 & 5 & 2 & 4 \\
\hline Dyspnea & $134^{*}$ & 2.27 & 1.2 & 2 & 1 & 4 & 1 & 4 \\
\hline Death & 135 & 2.22 & 1.35 & 1 & 1 & 5 & 1 & 4 \\
\hline Relapse of cancer & 135 & 2.06 & 1.27 & 1 & 1 & 4 & 1 & 3.5 \\
\hline
\end{tabular}

or other forms of further treatment, dyspnea, oxygen dependence, cancer relapse, physical pain and death. These values are presented in detail in Table 6.

To assess whether the readiness of lung cancer patients to accept limitations after surgery is affected by age, the Spearman correlation coefficient was used. It has been shown that age significantly influences the readiness to accept effort limitations ( $p=0.001$ ) and various forms of sporting activity $(p<0.001)$, work restrictions $(p<0.001)$, shortening the time of activities ( $p=0.001)$, social activity limitations $(p=0.029)$, long-term exhaustion and chronic fatigue $(p<0.001)$, dependence on others $(p=0.014)$, frequent hospital stays $(p=0.03)$ and infections $(p=0.06)$, dyspnea $(p=0.001)$, dependence on oxygen therapy $(p=0.017)$, cancer relapse $(p=0.04)$, physical pain $(p=0.001)$, death $(p<0.001)$. These dependencies are positive, which means that the older the patients, the more ready they are to accept changes. However, age has the strongest influence on the readiness to accept chronic fatigue $(r=0.326, p<0.001)$. Variables such as lifestyle changes, chemotherapy or other further treatment were not statistically significant $(p>0.05)$.

Mann-Whitney U test was also used to check how marital status affects patients' readiness to accept restrictions. The $p$-values lower than 0.05 were recorded for death, so the willingness to accept it depended on marital status. Married people were less likely to accept death than other patients $(p=0.025)$, but this did not depend on the number of children $(p>0.05)$.

The Kruskal-Wallis test was used to analyze the relationship between the acceptance of postoperative restrictions and education. The $p$-values turned out to be lower than 0.05 for 9 out of 17 analyzed consequences of the procedure, which clearly showed readiness to accept them related to education. To assess how exactly this relationship looks like, a post-hoc analysis was performed. It showed that patients with higher education more than patients with primary and secondary education are able to accept lifestyle changes $(p<0.017)$; patients with higher education less than other patients are able to accept limitations in their work $(p=0.008)$, reduced time to perform various activities $(p=0.024)$, reduced social activity ( $p=0.018)$, dyspnea $(p=0.001)$, dependence on oxygen therapy $(p=0.002)$ and physical pain $(p=0.001)$; patients with higher education are significantly less able to accept cancer relapse than patients with primary and secondary education ( $p=0.031$ ); patients with primary and secondary education are significantly more able to accept death than other patients $(p=0.002)$.

The readiness to accept consequences after the procedure also depended on employment. Pensioners and disability pensioners were able to accept them more than working people, except for lifestyle changes and chemotherapy or other further treatment (in these two issues the analyzed groups did not differ significantly) $(p>0.05)$.

Following the interpretation of own health perception it was verified that seven patients did not answer these questions and therefore they were omitted from the analysis, which was performed using Mann-Whitney $U$ test. The $p$-values lower than 0.05 were reported for social contact $(p=0.046)$ and dyspnea $(p=0.034)$, so those who considered themselves healthy were less likely to accept restrictions on social activity and dyspnea than those who considered themselves sick. In turn, taking into account the dependence of the assessment of health condition in 
Table 6. Gender and patients' willingness to accept changes in life after surgery

\begin{tabular}{|c|c|c|c|c|c|c|c|c|c|c|c|}
\hline \multicolumn{2}{|c|}{ Changes } & \multirow{2}{*}{$\begin{array}{c}\text { Gender } \\
\text { Man }\end{array}$} & \multirow{2}{*}{$\begin{array}{c}n \\
88\end{array}$} & \multirow{2}{*}{$\begin{array}{c}\text { Average } \\
3.33\end{array}$} & \multirow{2}{*}{$\begin{array}{c}\text { SD } \\
1.17\end{array}$} & \multirow{2}{*}{$\begin{array}{c}\text { Median } \\
4\end{array}$} & \multirow{2}{*}{$\begin{array}{c}\text { Min } \\
1\end{array}$} & \multirow{2}{*}{$\begin{array}{c}\text { Max } \\
5\end{array}$} & \multirow{2}{*}{$\begin{array}{c}\text { Q1 } \\
2\end{array}$} & \multirow{2}{*}{$\begin{array}{c}\text { Q3 } \\
4\end{array}$} & \multirow{2}{*}{$\begin{array}{c}p^{*} \\
0.257\end{array}$} \\
\hline A & Reduced physical effort & & & & & & & & & & \\
\hline & & Woman & 47 & 3.09 & 1.27 & 4 & 1 & 5 & 2 & 4 & \\
\hline \multirow[t]{2}{*}{ B } & \multirow{2}{*}{$\begin{array}{l}\text { Reduced various forms } \\
\text { of sport activity }\end{array}$} & Man & 88 & 3.33 & 1.17 & 4 & 1 & 5 & 2 & 4 & 0.408 \\
\hline & & Woman & 47 & 3.13 & 1.3 & 4 & 1 & 5 & 2 & 4 & \\
\hline \multirow[t]{2}{*}{ C } & \multirow{2}{*}{$\begin{array}{l}\text { Changes in lifestyle } \\
\text { w(no addiction) }\end{array}$} & Man & 88 & 4.38 & 0.76 & 5 & 2 & 5 & 4 & 5 & 0.086 \\
\hline & & Woman & 47 & 4.55 & 0.8 & 5 & 1 & 5 & 4 & 5 & \\
\hline \multirow[t]{2}{*}{ D } & \multirow[t]{2}{*}{ Lack of ability to work } & Man & 87 & 3.2 & 1.21 & 4 & 1 & 5 & 2 & 4 & 0.269 \\
\hline & & Woman & 47 & 2.94 & 1.28 & 4 & 1 & 5 & 2 & 4 & \\
\hline \multirow[t]{2}{*}{ E } & \multirow{2}{*}{$\begin{array}{l}\text { Shortening the time to } \\
\text { prepare various activities }\end{array}$} & Man & 88 & 3.22 & 1.2 & 4 & 1 & 5 & 2 & 4 & 0.482 \\
\hline & & Woman & 47 & 3.04 & 1.3 & 4 & 1 & 5 & 2 & 4 & \\
\hline \multirow[t]{2}{*}{$\mathrm{F}$} & \multirow{2}{*}{$\begin{array}{l}\text { Deprivation of social } \\
\text { contacts }\end{array}$} & Man & 88 & 3.11 & 1.21 & 4 & 1 & 5 & 2 & 4 & 0.649 \\
\hline & & Woman & 47 & 3.23 & 1.16 & 4 & 1 & 5 & 2 & 4 & \\
\hline \multirow[t]{2}{*}{ G } & \multirow[t]{2}{*}{ Chronic exhaustion } & Man & 88 & 2.75 & 1.24 & 3 & 1 & 5 & 2 & 4 & 0.522 \\
\hline & & Woman & 47 & 2.6 & 1.06 & 2 & 1 & 4 & 2 & 4 & \\
\hline \multirow[t]{2}{*}{$\mathrm{H}$} & \multirow[t]{2}{*}{ Chronic fatigue } & Man & 88 & 2.74 & 1.29 & 3 & 1 & 5 & 2 & 4 & 0.518 \\
\hline & & Woman & 47 & 2.57 & 1.12 & 2 & 1 & 4 & 2 & 4 & \\
\hline \multirow[t]{2}{*}{1} & Dependence on other & Man & 88 & 2.95 & 1.24 & 3 & 1 & 5 & 2 & 4 & 0.424 \\
\hline & & Woman & 47 & 2.77 & 1.31 & 2 & 1 & 5 & 2 & 4 & \\
\hline J & Frequent hospital stays & Man & 88 & 2.82 & 1.22 & 3 & 1 & 5 & 2 & 4 & 0.131 \\
\hline & & Woman & 47 & 2.49 & 1.16 & 2 & 1 & 4 & 2 & 4 & \\
\hline K & Chemotherapy or other & Man & 88 & 3.48 & 1.18 & 4 & 1 & 5 & 3 & 4 & 0.032 \\
\hline & Torms or turther treatment & Woman & 47 & 2.96 & 1.37 & 4 & 1 & 5 & 2 & 4 & \\
\hline$L$ & Frequent infections & Man & 88 & 2.78 & 1.2 & 3 & 1 & 4 & 2 & 4 & 0.339 \\
\hline & & Woman & 47 & 2.57 & 1.16 & 2 & 1 & 4 & 2 & 4 & \\
\hline M & Dyspnea & Man & 87 & 2.46 & 1.25 & 2 & 1 & 4 & 1 & 4 & 0.019 \\
\hline & & Woman & 47 & 1.91 & 1.02 & 2 & 1 & 4 & 1 & 2 & \\
\hline N & Dependence on oxygen & Man & 88 & 1.9 & 1.07 & 2 & 1 & 4 & 1 & 2.25 & $<0.001$ \\
\hline & therapy & Woman & 47 & 1.3 & 0.66 & 1 & 1 & 4 & 1 & 1 & \\
\hline $\mathrm{O}$ & Relapse of cancer & Man & 88 & 2.26 & 1.29 & 2 & 1 & 4 & 1 & 4 & 0.006 \\
\hline & & Woman & 47 & 1.68 & 1.16 & 1 & 1 & 4 & 1 & 2 & \\
\hline P & Physical pain & Man & 88 & 3 & 0.99 & 3 & 1 & 4 & 2 & 4 & 0.001 \\
\hline & & Woman & 47 & 2.34 & 1.11 & 2 & 1 & 4 & 2 & 3.5 & \\
\hline Q & Death & Man & 88 & 2.41 & 1.35 & 2 & 1 & 4 & 1 & 4 & 0.02 \\
\hline & & Woman & 47 & 1.87 & 1.3 & 1 & 1 & 5 & 1 & 3 & \\
\hline
\end{tabular}

comparison with the period from before the year, it was shown that people who considered their health condition improved or did not change were less likely to accept death than other patients $(p=0.006)$.

The assessment of readiness to accept life changes did not depend on the place of residence $(p>0.05)$.

In order to get to know the complexity of the discussed issue, the analysis of the examined sample was performed not only from the level of two features, i.e. the AIS and readiness to accept functional limitations after surgical treatment, but it was also checked whether they are related to each other.
The Spearman correlation coefficient was used for this analysis. The study showed that the degree of disease acceptance significantly affects the readiness to accept chemotherapy or other forms of further treatment. This correlation is positive, which means that the greater the acceptance of the disease, the greater the willingness to accept chemotherapy or other forms of further treatment (Table 7).

\section{Discussion}

The progress of knowledge about lung cancer is increasingly focused on precise criteria for assessing the severity 
Table 7. Correlation between readiness to accept the changes in life after surgery and acceptance of illness

\begin{tabular}{|c|c|c|c|c|c|}
\hline \multicolumn{2}{|c|}{ Changes } & \multicolumn{4}{|c|}{ Correlation with AIS } \\
\hline & & \multirow{2}{*}{$\begin{array}{c}\text { Correlation } \\
\text { coefficient } \\
0.141\end{array}$} & \multirow{2}{*}{$\begin{array}{c}p \\
0.102\end{array}$} & \multirow{2}{*}{$\begin{array}{l}\text { Correlation } \\
\text { relationship } \\
\text { direction } \\
-\end{array}$} & \multirow{2}{*}{$\begin{array}{c}\text { Strength } \\
\text { of correlation } \\
\text { dependence } \\
-\end{array}$} \\
\hline A & Reduced physical effort & & & & \\
\hline B & Reduced various forms of sport activity & 0.15 & 0.083 & - & - \\
\hline C & Changes in lifestyle (no addiction) & 0.077 & 0.374 & - & - \\
\hline D & Lack of ability to work & 0.084 & 0.337 & - & - \\
\hline$E$ & Shortening the time to prepare various activities & 0.075 & 0.384 & - & - \\
\hline $\mathrm{F}$ & Deprivation of social contacts & -0.021 & 0.813 & - & - \\
\hline G & Chronic exhaustion & 0.096 & 0.266 & - & - \\
\hline $\mathrm{H}$ & Chronic fatigue & 0.092 & 0.29 & - & - \\
\hline । & Dependence on other people & 0.11 & 0.204 & - & - \\
\hline J & Frequent hospital stays & 0.118 & 0.174 & - & - \\
\hline K & Chemotherapy or other forms of further treatment & 0.224 & 0.009 & Positive & Very weak \\
\hline L & Frequent infections & 0.036 & 0.68 & - & - \\
\hline M & Dyspnea & 0.019 & 0.832 & - & - \\
\hline N & Dependence on oxygen therapy & 0.008 & 0.925 & - & - \\
\hline 0 & Relapse of cancer & 0.107 & 0.216 & - & - \\
\hline$P$ & Physical pain & 0.016 & 0.852 & - & - \\
\hline Q & Death & -0.063 & 0.469 & - & - \\
\hline
\end{tabular}

AIS - Acceptance of Illness Scale

of the disease. In terms of treatment, it includes primarily the introduction of combined therapy, the development of a new TNM classification (based on tumor size assessment $(\mathrm{T})$, lymph node involvement $(\mathrm{N})$ and presence of distant metastases $(M)$, which is the basis for choosing the right treatment method, the development of radiotherapy, and the introduction of more effective systemic treatment regimens [17]. This makes it possible to develop the best and least invasive method of treatment for the patient, which not only brings the medical aspect of healing with it but can also affect mental comfort and better acceptance of the disease and its limitations. Moreover, the choice of surgery with less pain and less invasiveness results in a shorter hospital stay and a better quality of postoperative life [18]. For an oncological patient, it is important not only to provide information on the method of treatment, but also on its consequences. What is more, the fact that the operation is to take place is often associated with fear for health and life, and future changes in family, professional and social functioning that may occur as a result of the operation, even if it is fully successful in terms of oncology. Patients are often unable to imagine the course of the operation, thus projecting undesirable fears and anxieties. This is often accompanied by anxiety about possible complications, general anesthesia, loss of control over one's behavior after drugs that exclude consciousness and further life with limitations after lung resection [19]. It is therefore very important for the patient to meet with a surgeon who will operate on him/her before the planned surgery. Moreover, the level of knowledge of the medical personnel about this subject and/or its improper transfer also has a significant impact on adaptation to the disease [11]. All this may lead to a number of psychological complications. However, this study shows that the awareness of the effects and consequences of treatment among patients prepared for surgery for lung cancer is high. Therefore, it can be concluded that the information provided by doctors in this area is reliable and effective.

Patients with lung cancer face numerous inconveniences associated with everyday functioning. It is believed in the literature that fatigue is the most frequently reported symptom of cancer and the therapy used. Other most troublesome symptoms include pain, nausea, lack of appetite, diarrhea, constipation and sleep disorders [20]. As shown by the study of Caus et al. [21], a major problem for cancer patients is also related to the dependence on medical personnel and the change in the relationship between the patient and his/her relatives. Patients also often suffer from psychological complications, including depression. Polsky et al. [22] in a study on the risk of depression in patients with cancer, diabetes, hypertension, heart disease, rheumatoid arthritis, chronic lung disease or after a stroke, found that 2 years after their diagnosis, it was lung cancer patients who were 3.5 times more likely to develop depression than other groups. The threat is also not posed by anxiety syndromes in the form of generalized anxiety or phobia leading to panic anxiety and the socalled "respiratory panic", i.e. a condition evoking extreme emotions, such as anxiety of suffocation. This is confirmed by the data obtained in the present study, in which it has been unequivocally demonstrated that patients prepared for surgery due to lung cancer in the smallest degree are 
ready to accept, apart from death and relapse of cancer, the dependence on oxygen therapy and dyspnea.

Interestingly, it has been noted that the readiness to accept changes and/or consequences associated with treatment after surgery depends on the degree of acceptance of the disease. The AIS score in the examined sample of lung cancer patients was 32.23 points, which means quite high level of its acceptance. However, these values are significantly higher than those of patients treated for lung cancer included in the works of other authors, who scored 27.21 points [11], 27.10 points [18] and 23.17 points. [23]. Research in this area was also conducted by Nowicki et al. [24] comparing the degree of disease acceptance in lung cancer patients before and after surgery. Interestingly, before the surgery, the average score on the acceptance scale was 26.2 points, and after the surgery -20.89 points, which means that its level decreased. Other studies have shown that people with lung cancer show significantly lower levels of acceptance than those with other lung diseases $[20,25]$. Comparing the degree of disease acceptance with patients treated for another type of cancer, it is also higher than that of women with breast and uterine cancer [12], cancer of cervix [26], colorectal cancer [20], breast cancer [27], among women after mastectomy [28] and leukemia patients [29].

The Ogińska-Bulik analysis [30] shows that the degree of disease acceptance is age-related. However, the results obtained in our own studies do not confirm these relationships. Similarly, Pawlik and Karczmarek-Borowska [31] and Dońka et al. [32] did not show statistically significant differences between age and acceptance of the disease among breast cancer patients. Similar results are reported by Czerw et al. [23] in patients with lung cancer. However, different data were published by Latalski et al. [33] indicating that younger women with breast cancer have a higher level of disease acceptance than older women. Similarly, Niedzielski et al. [34] in their studies emphasize the statistically significant dependence of the level of disease acceptance on age (a higher level of disease acceptance is characteristic for people under 55 years of age). However, this study shows that age affects the willingness to accept most of the analyzed consequences after surgery for lung cancer, apart from lifestyle changes and chemotherapy or other further treatment. These correlations are positive, which means that the higher the age, the greater the readiness to accept these changes. Negative effects of chemotherapy on acceptance of the disease have also been reported by Religoni et al. [35] in patients with colorectal cancer. Moreover, patients who did not undergo it achieved a slightly higher AIS score than those who received such treatment. Age has the strongest influence on the acceptance of chronic fatigue,

Niedzielski et al. [34] also indicate a relationship between the level of acceptance of the disease and gender (higher acceptance level was found in men). However, statistical analysis of own research does not confirm the influence of gender on the level of disease acceptance. Interestingly, however, such dependence has been demonstrated in terms of readiness to accept potential changes in life after surgery. Women less than men were willing to accept chemotherapy or other forms of further treatment, dyspnea, oxygen dependence, cancer relapse, physical pain and death. A better acceptance of the consequences of treatment was also demonstrated by Ogińska-Bulik [30] among women after radical breast cancer treatment.

The analysis showed that the degree of disease acceptance also does not depend on the place of residence. Similar results are indicated by Pawlik and Karczmarek-Borowska [31] among women with breast cancer. However, this data is not confirmed by the studies by Nowicki et al. [36] and Niedzielski et al. [34], which noted that women living in the city had a higher degree of acceptance of the disease. However, this can be explained by the fact that cities offer better access to information and health services, including psychological care.

The analysis of the data also did not show any correlation between education and the level of lung cancer acceptance. Similar results were reported by other authors [31]. Interestingly, however, patients with higher education after lung cancer surgery were more willing than others to accept a change in their lives after the surgery. This may be due to greater awareness of the disease and motivation to gain knowledge about it, or simply the desire to return to professional activity and accomplish themselves in this area.

From the public health perspective, a very important task is to establish the relationship between patients' perception of their own illness and their predispositions to undertake pro-healthy behavior, to assess their health condition during the course of the illness and after the completion of treatment. It seems probable that patients who show more responsibility for their health, perceive their illness as less distressing. This is not confirmed by this study, which notes that the degree of lung cancer acceptance depends on the assessment of health condition in comparison with a year before. Patients who consider it the same or better than a year before have a higher level of disease acceptance. Interestingly, a study by Nowicki and Ostrowska [37] showed a reverse relationship in this regard, which means that the passage of time did not affect the acceptance of breast cancer. These studies were repeated after 6 months, but it seems that the time up to a few months after surgery may be too short to show statistically significant differences in this period. Taking into account the above, the psychological activation of patients and the increase in their perception of the possibility of influencing their own health may therefore have a positive impact on the acceptance of limitations resulting from the disease and the consequences of treatment, and thus optimization of the health care system costs.

The process of studies in patients with lung cancer was particularly difficult due to the prevailing emotional tension associated with the stay in hospital, waiting for surgery and filling in the questionnaires. The latter turned out to be a bit problematic for some patients, because they not only touched on topics from their personal lives, but above all through questions about the level of acceptance of the disease and limitations after the surgery, they often reminded the patients why they were in hospital and about the difficult moments to come. It could be noticed 
that some patients, especially men, during the conversation, tried to underestimate the problem and mask it with a smile. Each time, however, the conversation with the patient was much more than just a scientific study. The patients touched on many threads from their personal lives, sometimes expressing extreme and often accumulated emotions. All those who agreed to take part in the research were provided with psychological care both before and immediately after surgery and during the rehabilitation period. It was noticeable that the anxiety and tension was reduced by the doctor explaining the course of treatment to the patient, the actual situation, and explaining the circumstances in which the patient will find himself/herself after the surgery. The medical equipment connected to the patient was a source of great anxiety. Comfort was brought about by a thorough explanation of the purpose of such medical procedures and psychological support. The strength of this study is therefore the answer to many important questions not only from the psychological but also oncological point of view. The knowledge of the awareness of the effects and consequences of surgical treatment among patients with lung cancer and the level of acceptance of the disease and their readiness to accept limitations after surgical treatment should facilitate the understanding of the needs of the oncological patients, their behavior and reaction to the disease, thus becoming a valuable indication in the management of the patient and his/her family. However, the research carried out has several limitations. Firstly, the data were collected from only one center. Secondly, despite the use of standardized tools and a relatively large number of patients, the undoubted limitation of this study is not taking into account the sense of coherence in the context of coping with cancer, which would surely contribute even better to the presentation of a fuller picture of the issues addressed. The authors of this paper plan to raise this problem in future studies.

\section{Conclusions}

Awareness of the effects and consequences of treatment is very high among patients preparing for surgery for lung cancer. The degree of acceptance of the disease is higher in patients who consider themselves healthy and those assessing their condition as good, both nowadays and in comparison with a year before. After surgery, the patients are most willing to accept such changes as getting rid of addictions, undergoing chemotherapy and other forms of treatment, limiting various forms of sports activities and physical effort. Women are less willing to accept changes in life after surgery. The higher the age, the greater the readiness to accept changes.

Patients with higher education are more likely to accept lifestyle changes, but less likely to accept limitations in their work, reduced time for various activities, reduced social activity, dyspnea, dependence on oxygen therapy, physical pain, cancer relapse and death. Pensioners are more likely than working people to accept the consequences of the procedure, except for lifestyle changes and chemotherapy or other further treatment. People who consid- er themselves healthy are less likely to accept restrictions on social activity and dyspnea. The willingness to accept death is lower in married people. Acceptance of changes in life after surgery is lower in people who think that their health has improved or has not changed.

\section{The authors declare no conflict of interest.}

\section{References}

1. Domagała-Kulawik J. Rak płuca. In: Pneumonologia praktyczna. Chazan R (ed.). $\alpha$-medica press, Bielsko-Biała 2005: 532.

2. Włodarska-Polińska I, Koń B, Więckowska B. Model struktury leczenia w nowotworach płuc. In: Proces leczenia w Polsce - analizy i modele. Tom I: Onkologia, Więckowska B (ed.). Ministerstwo Zdrowia, Warszawa 2015: 113-140.

3. Didkowska J, Wojciechowska U. Krajowy Rejestr Nowotworów. Nowotwory złośliwe w Polsce w 2013 roku. http://onkologia.org. pl/wp-content/uploads/BIUL2013.pdf (access: 19.03.2017).

4. Krawczyk P, Ramlau R, Spychalski Ł, Świerzewski R. Rak płuca - standardy diagnostyki i leczenia w Polsce. Raport. Fundacja Wygrajmy Zdrowie, Warszawa 2015: 6.

5.Zieliński M, Kużdżał J. Resekcje miąższu płucnego In: Podstawy chirurgii: podręcznik dla lekarzy specjalizujących się w chirurgii ogólnej. Tom II, Szmidt J (ed.). Medycyna Praktyczna, Kraków 2004: 318-325.

6. Chabowski M, Orłowski TM, Rabczenko D. Analysis of prognostic factors and efficacy of surgical treatment for non-small cell lung cancer: department of surgery NTLDRI (1998-1999). Pneumonol Alergol Pol 2008; 76: 1-10.

7. de Walden-Gałuszko K. Psychoonkologia w praktyce klinicznej. PZWL, Warszawa 2015: 29-76.

8. Kużdżał J. Fizjoterapia w chirurgii klatki piersiowej. Alma Mater 2011; 140: 58-61.

9. Lambley P. Psychologia raka: jak zapobiegać, jak przeżyć. Książka i Wiedza, Warszawa 1995: 43.

10. Barraclough J. Rak i emocje. Praktyczny przewodnik po psychoonkologii. Wydawnictwo Medyczne Sanmedica, Warszawa 1997: 43-65.

11. Nowicki A, Sianoszek P, Farbicka P. Sense of coherence and acceptance of the disease in patients with lung cancer during palliative chemotherapy. Contemp Oncol 2019; 23: 157-163.

12. Juczyński Z. Narzędzia pomiaru w promocji zdrowia. Pracownia Testów Psychologicznych Polskiego Towarzystwa Psychologicznego, Warszawa 2001: 134-139; 168-172.

13. Folstein MF, Folstein SE, McHugh PR. "Mini-mental state". A practical method for grading the cognitive state of patients for the clinician. J Psychiatr Res 1975; 12: 189-198.

14. Stańczak J. MMSE. Polska normalizacja. Pracownia Testów Psychologicznych Polskiego Towarzystwa Psychologicznego, Warszawa 2010: 12 .

15. Felton BJ, Revenson TA. Coping with chronic illness: a study of illness controllability and the influence of coping strategies on psychological adjustment. J Consult Clin Psychol 1984; 52: 343-353.

16. R Core Team. R. A language and environment for statistical computing. R Foundation for Statistical Computing, Vienna, Austria 2017. https://www.R-project.org/.

17. Rzyman W. Rak płuca. Forum Med Rodz 2008; 6: 407-417.

18. Chabowski M, Polański J, Jankowska-Polanska B, Lomper K, Janczak D, Rosinczuk J. The acceptance of illness, the intensity of pain and the quality of life in patients with lung cancer. J Thorac Dis 2017; 9: 2952-2958.

19. Jacobsen PB, Roth AJ, Holland JC. Surgery. In: Psycho-oncology, Holland JC (ed.). Oxford University Press, New York 1998: 257-269.

20. Kapela I, Bąk E, Krzemińska SA, Foltyn A. Evaluation of the level of acceptance of the disease and of satisfaction with life in patients with colorectal cancer treated with chemotherapy. Piel Zdr Publ 2017; 26: 53-61. 
21. Caus I, Naworska B, Kamińska J. Psychospołeczne problemy pac jentów z chorobą nowotworową. Annales UMCS 2003; Sectio D: Medicina 58 (Suppl 13): 172-179.

22. Polsky D, Doshi JA, Marcus S, Oslin D, Rothbard A, Thomas N, Thompson CL. Long-term risk for depressive symptoms after a medical diagnosis. Arch Intern Med 2005; 165: 1260-1266.

23. Czerw Al, Religioni U, Deptała A. Adjustment to Life with Lung Cancer. Adv Clin Exp Med 2016; 25: 733-740.

24. Nowicki A, Graczyk P, Lemanowicz M. The acceptance of illness in lung cancer patients before and after surgical treatment. Pol Przegl Chir 2017; 89: 11-15.

25. Mącik D, Fijałkowska S, Nycz K. Valuing crisis, acceptance of illness and social support among people suffering from lung cancer Współczesna Onkol 2011; 15: 376-380.

26. Kaźmierczak M, Kubia I, Gebuza G, Gierszewska M, Mieczkowska E. Czynniki determinujące akceptację choroby przez kobiety lec zone z powodu zmian patologicznych szyjki macicy. Med Ogólna Nauki Zdr 2015; 21: 181-186.

27. Kozieł P, Lomper K, Uchmanowicz B, Polański J. Association be tween acceptance of illness, anxiety and depression with assess ment quality of life of breast cancer patients. Medycyna Paliatywna w Praktyce 2016; 10: 28-36.

28. Bąk-Sosnowska M, Oleszko K, Skrzypulec-Plinta V. Adaptacja psychologiczna dojrzałych kobiet w pierwszych dobach po zabiegu mastektomii. Przegl Menopauzal 2013; 2: 120-124.

29. Wiraszka G, Lelonek B. The functioning of a patient with leukemia and the acceptance of neoplastic disease. Medical Studies 2008; 10: 21-26.

30. Ogińska-Bulik N. Rola prężności psychicznej w przystosowaniu się kobiet do choroby nowotworowej. Psychoonkologia 2011; 1: 1-10.

31. Pawlik M, Karczmarek-Borowska B. Akceptacja choroby nowotworowej u kobiet po mastektomii. Przegląd Medyczny Uniwersytetu Rzeszowskiego i Narodowego Instytutu Leków 2013; 2 : 203-211.

32. Dońka K, Kanadys K, Lewicka M, Baran B, Wiktor H. Reakcje kobiet na rozpoznanie zmian guzowatych i choroby nowotworowej piersi. Annales UMCS 2005; Sectio D: Medicina 60 (Suppl 16): 357-362.

33. Latalski M, Kulik TB, Skórzyńska H, Żołnierczuk-Kieliszek D. Rozpoznanie raka sutka u kobiet - implikacje psychospołeczne. Wiad Lek 2001; 54: 390-398.

34. Niedzielski A, Humeniuk E, Błaziak P, Fedoruk D. Stopień akceptacji choroby w wybranych chorobach przewlekłych. Wiad Lek 2007; 60: 224-227.

35. Religioni U, Czerw A, Deptała A. Acceptance of Cancer in Patients Diagnosed with Lung, Breast, Colorectal and Prostate Carcinoma. Iran J Public Health 2015; 44: 1135-1142.

36. Nowicki A, Kwasińska E, Rzepka K, Walentowicz M, Grabiec M. Wpływ choroby na życie emocjonalne kobiet po operacji raka piersi zrzeszonych w klubach „Amazonka”. Annales Academiae Medicae Stetinensis 2009; 55: 81-85.

37. Nowicki A, Ostrowska Ż. Akceptacja choroby przez chore po op eracji raka piersi w trakcie leczenia uzupełniającego. Pol Merkur Lekarski 2008; 24: 403-407.

\section{Address for correspondence}

\section{Katarzyna Białek}

Institute of Medical Sciences

Faculty of Medicine and Health Sciences Jan Kochanowski University

19A IX Wieków Kielc Ave.

25-317 Kielce, Poland

katarzynabialek@vp.pl

Submitted: 8.03.2020

Accepted: 23.03.2020 